\title{
How sustainable is it?
}

Citation for published version (APA):

van der Meer, Y. (2021). How sustainable is it? That is the question. Maastricht University. https://doi.org/10.26481/spe.20210611ym

Document status and date:

Published: 11/06/2021

DOI:

10.26481/spe.20210611ym

Document Version:

Publisher's PDF, also known as Version of record

\section{Please check the document version of this publication:}

- A submitted manuscript is the version of the article upon submission and before peer-review. There can be important differences between the submitted version and the official published version of record.

People interested in the research are advised to contact the author for the final version of the publication, or visit the DOI to the publisher's website.

- The final author version and the galley proof are versions of the publication after peer review.

- The final published version features the final layout of the paper including the volume, issue and page numbers.

Link to publication

\footnotetext{
General rights rights.

- You may freely distribute the URL identifying the publication in the public portal. please follow below link for the End User Agreement:

www.umlib.nl/taverne-license

Take down policy

If you believe that this document breaches copyright please contact us at:

repository@maastrichtuniversity.nl

providing details and we will investigate your claim.
}

Copyright and moral rights for the publications made accessible in the public portal are retained by the authors and/or other copyright owners and it is a condition of accessing publications that users recognise and abide by the legal requirements associated with these

- Users may download and print one copy of any publication from the public portal for the purpose of private study or research.

- You may not further distribute the material or use it for any profit-making activity or commercial gain

If the publication is distributed under the terms of Article $25 \mathrm{fa}$ of the Dutch Copyright Act, indicated by the "Taverne" license above, 
Maastricht University

\section{Inaugural speech}

Prof. Dr. Yvonne van der Meer

Faculty of Science and Engineering

How sustainable is it? That is the Question 
Geachte mevrouw de rector magnificus, zeer gewaardeerde collega's, lieve familie en vrienden, beste studenten, beste samenwerkingspartners en alle belangstellenden. Wat fijn dat jullie hier vandaag zijn en ook online aanwezig zijn voor mijn oratie. Ik heb echt uitgekeken naar deze dag en dit moment, dat door een of ander virus wat later kwam dan ik had verwacht. Toen ik vandaag aankwam bij de coronakamer, kreeg ik het even benauwd, maar het gaat nu echt beginnen. De titel van mijn oratie is "How sustainable is it? That is the question". Hoe duurzaam is het? Dat is de vraag die centraal staat in het onderzoek van mijn leerstoel "Sustainability of Chemicals and Materials". De vraag "Hoe duurzaam is het? wordt gelukkig de laatste jaren steeds vaker gesteld. Het antwoord is niet altijd eenvoudig te geven en daarover gaat dit openbare college.

\section{Duurzaamheid}

Voordat je de vraag "Hoe duurzaam is het?" kunt beantwoorden moet je weten wat duurzaamheid eigenlijk inhoudt. Een jaar na mijn geboorte werd het rapport "Limits to Growth", oftewel "De grenzen aan de groei" van de Club van Rome gepubliceerd. Daarin werd voor de eerste keer in de geschiedenis geconstateerd dat er grenzen zijn aan de ecologische voetafdruk van de mensheid, omdat de draagkracht van de aarde beperkt is [1,2]. Deze voetafdruk was enorm gestegen tussen 1900 en 1972 door bevolkingsgroei, voedselproductie, industriële productie, het toenemend gebruik van natuurlijke hulpbronnen en de hoeveelheid afval die in ons milieu terecht kwam. De auteurs berekenden dat de waargenomen groei maximaal 100 jaar zou kunnen voortduren om de grens van de draagkracht van de aarde te bereiken. Het rapport stelde ook dat een samenleving tijd nodig heeft om een gewenste aanpak te formuleren en deze tot uitvoering te brengen. In die tijd gaat de groei door met het risico dat duurzaamheidsgrenzen die ook gevolgen hebben voor de mensheid overschreden worden. Zij concludeerden dan ook dat er toekomstgericht beleid nodig is om de ecologische voetafdruk te beperken.

\section{What is sustainability?}

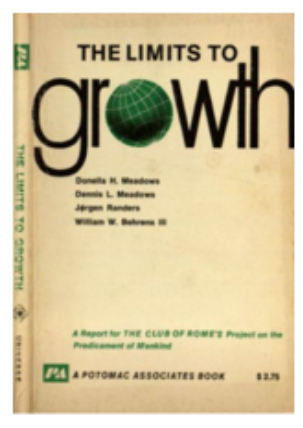

$\$$ Maastricht University
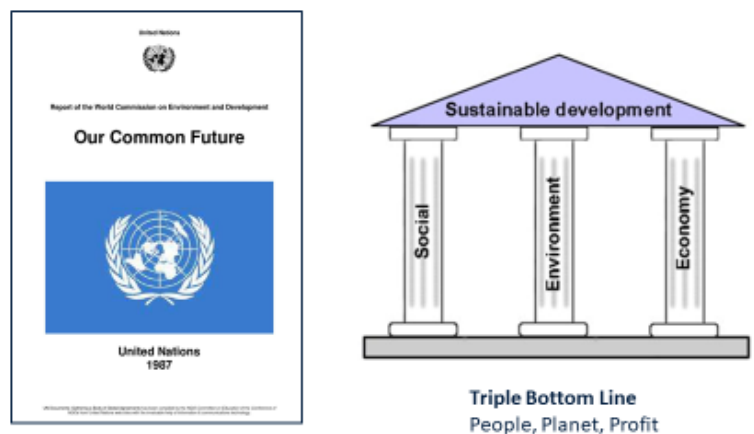

People, Planet, Profit

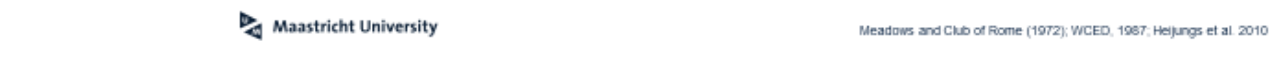

Overgenomen uit [3]: Heijungs, R., Huppes, G., \& Guinée, J. B. (2010). Life cycle assessment and sustainability analysis of products, materials and technologies. Toward a scientific framework for sustainability life cycle analysis. Polymer Degradation and Stability, 95(3), 422-428.

Dit toekomstgericht denken komt terug in het rapport "Our Common future" van de Brundtland commissie. Daarin wordt duurzame ontwikkeling gedefinieerd als "de ontwikkeling die voorziet in de behoeften van de huidige generatie, zonder de behoeften van toekomstige generaties in gevaar te brengen" [4]. We moeten er dus voor zorgen dat we de aarde leefbaar achterlaten voor onze kinderen en kleinkinderen. Maar hoe doen we dat? John Elkington bedacht de "triple-bottom-line" [5] om 
organisaties te helpen naar een duurzame toekomst toe te werken. In zijn concept bestaat duurzaamheid uit drie pijlers: een economische, een milieu- en een sociale pijler. Dit wordt ook wel aangeduid als "People, Planet, Profit", en wordt nog steeds gebruikt als leidraad voor duurzame ontwikkeling. De triple-bottom-line was een oproep om evenveel aandacht te besteden aan sociale en milieuaspecten als aan economische aspecten. Op dit moment zien we nog steeds dat economische overwegingen leidend zijn in onze maatschappij.

Om duurzame ontwikkeling te stimuleren zijn er in de loop der jaren tal van afspraken tussen landen gemaakt om bepaalde doelen te halen. In 2015 werd het Klimaatakkoord van Parijs aangenomen, waarin landen afspraken hebben gemaakt om de klimaatverandering te beperken tot maximaal 2 graden Celsius vergeleken met het pre-industriële niveau [6]. Klimaatverandering wordt veroorzaakt door uitstoot van broeikasgassen, zoals $\mathrm{CO}_{2}$ en methaan. Maar duurzame ontwikkeling kent veel meer aspecten dan klimaatverandering. De 2030 agenda voor duurzame ontwikkeling die is aangenomen door alle VN-lidstaten in 2015, presenteert een gemeenschappelijke visie op vrede en welvaart voor mens en planeet. De 17 Sustainable Development Goals vormen de kern: 17 werelddoelen voor duurzame ontwikkeling, die in 2030 bereikt moeten zijn [7]. Akkoorden en gezamenlijke doelen leken lange tijd redelijk vrijblijvend te zijn. We hebben de afgelopen periode gezien dat het naleven meer en meer wordt afgedwongen via juridische procedures.

\section{Sustainability Goals and Planetary Boundaries}
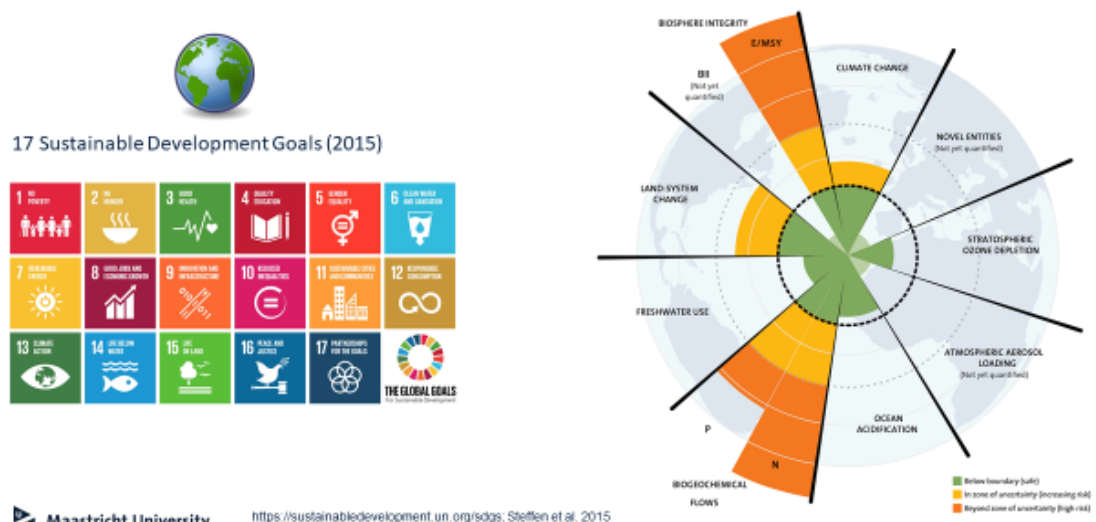

Overgenomen uit [7,8]: THE 17 GOALS | Sustainable Development, United Nations, 2020, https://sdgs.un.org/goals ; Steffen, W., Richardson, K., Rockström, J., Cornell, S., Fetzer, I., Bennett, E., Biggs, R., and Carpenter, S. (2015), Planetary boundaries: Guiding human development on a changing planet. Science (New York, N.Y.), 348(6240), 1217. Reprinted with permission; readers may view, browse, and/or download material for temporary copying purposes only, provided these uses are for noncommercial personal purposes. Except as provided by law, this material may not be further reproduced, distributed, transmitted, modified, adapted, performed, displayed, published, or sold in whole or in part, without prior written permission from the publisher

En hoe is het nu gesteld met ons leefmilieu op aarde? In 2009 publiceerde een groep wetenschappers, onder leiding van Johan Rockström van het Stockholm Resilience Centre in Zweden, een onderzoek waarin negen processen werden geïdentificeerd die de stabiliteit en de veerkracht van de aarde reguleren. Voor alle processen zochten zij de veilige grenzen waarbinnen geen grote veranderingen te verwachten zijn, aangegeven in groen in deze figuur van de zogenaamde planetaire grenzen [8]. Overschrijding van deze grenzen verhoogt het risico van grootschalige plotselinge of onomkeerbare veranderingen van de aarde en vormt dus een risico voor het leefmilieu van de mens [9]; dit is 
aangegeven in geel. Klimaatverandering en verandering in landgebruik zitten in de gele zone. Oranje betekent een hoog risico op onomkeerbare veranderingen. Dit hoge risico geldt voor de stikstof en de fosfor kringlopen en ook voor de biodiversiteit, dat is hoeveel verschillende soorten we op aarde hebben. Dit vormt weer een risico voor onze landbouw en daarmee onze voedselvoorziening. Dus ondanks vele duurzaamheidsakkoorden en technologische vooruitgang van de afgelopen tientallen jaren staat de aarde er niet goed voor. Ik denk dat we de aarde zo niet achter kunnen laten voor onze kinderen en kleinkinderen. Er zijn echt grote veranderingen nodig om aan de volgende generaties ook een leefbare aarde door te geven.

\section{Materialen}

Laten we ons vandaag beperken tot de trends en de benodigde veranderingen in materialen die we in ons dagelijks leven veel gebruiken, de polymere materialen.

\section{Trends in materials development}

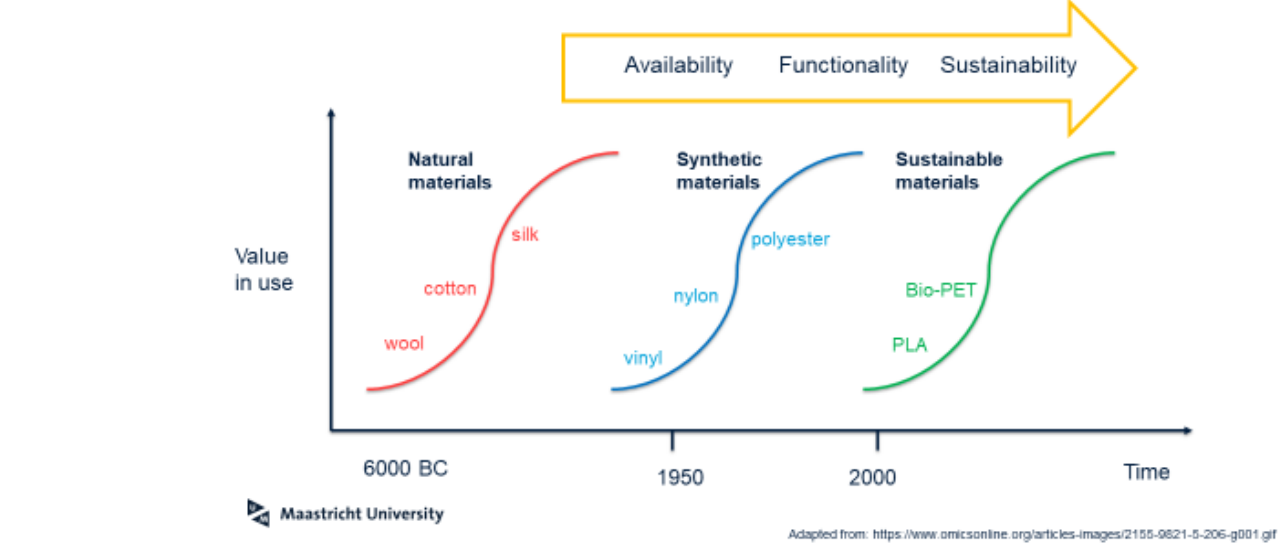

Aangepast overgenomen uit https://www.omicsonline.org/articles-images/2155-9821-5-206-g001.gif [10]

Lang geleden kende we al natuurlijke materialen, zoals wol, katoen en zijde; die materialen gebruiken we nog steeds. Halverwege de vorige eeuw kwam daar een nieuwe generatie materialen bij: synthetische polymere materialen gemaakt uit aardolie met fantastische eigenschappen, die wij kennen als plastics. Plastics vervullen veel belangrijke functies in ons leven en een leven zonder plastics is moeilijk meer voor te stellen. Denk hierbij aan verpakkingen, kunststof leidingen, auto-onderdelen, maar ook de beschermingsmiddelen die we gebruiken tegen verspreiding van het coronavirus.

Inmiddels zijn we begonnen aan de transitie naar een nieuwe klasse van materialen die wel deze functies hebben, maar die ook duurzamer zijn dan hun voorgangers. Dit heeft te maken met twee grote duurzaamheidsproblemen.

In de eerste plaats is er klimaatverandering. Plastics worden gemaakt uit polymeren die zijn gemaakt van chemicaliën die uit fossiele grondstoffen worden gemaakt. Hoewel fossiele grondstoffen lang geleden uit plantaardige en dierlijke materialen zijn gevormd, verbruiken we deze grondstoffen veel sneller dan ze worden gevormd. Als plastics na gebruik worden verbrand, wordt er versneld veel $\mathrm{CO}_{2}$ uitgestoten; dit leidt tot klimaatverandering. 


\section{Carbon cycle in a fossil-based economy}
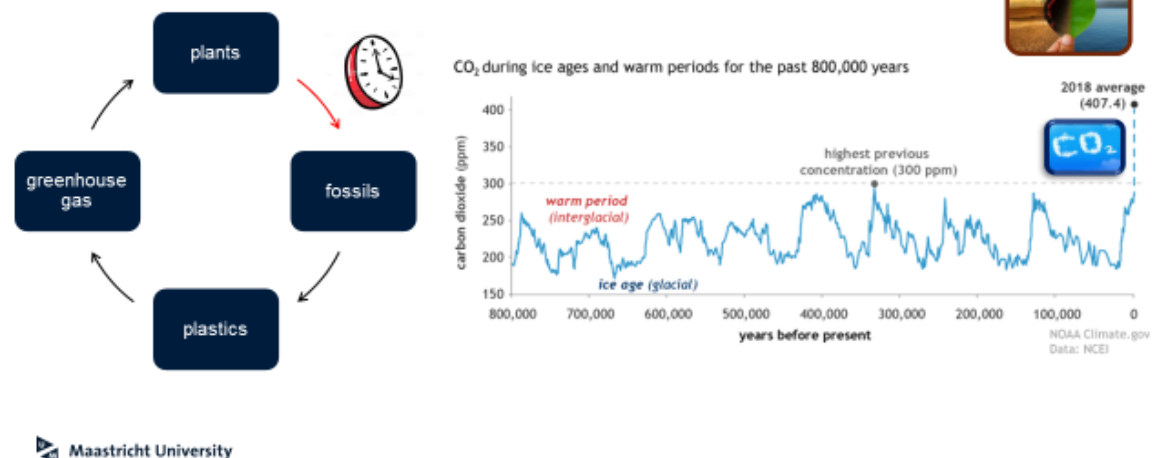

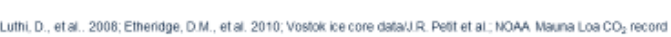

Aangepast overgenomen uit: " $\mathrm{CO}_{2}$ during ice ages and warm periods for the past 800,000 years", www.climate.gov

Als we materialen uit planten maken, dan wordt $\mathrm{CO}_{2}$ eerst opgenomen door de plant en bij verbranding van het plastic komt weer $\mathrm{CO}_{2}$ vrij, maar dit verloopt dan in een gebalanceerde kringloop van verbruik en uitstoot. Wat we graag willen is de natuur gebruiken als bron voor onze materialen, net als vroeger, maar de materialen moeten wel de eigenschappen hebben van de materialen van nu.

\section{Carbon cycle in a biobased economy - bioplastics}

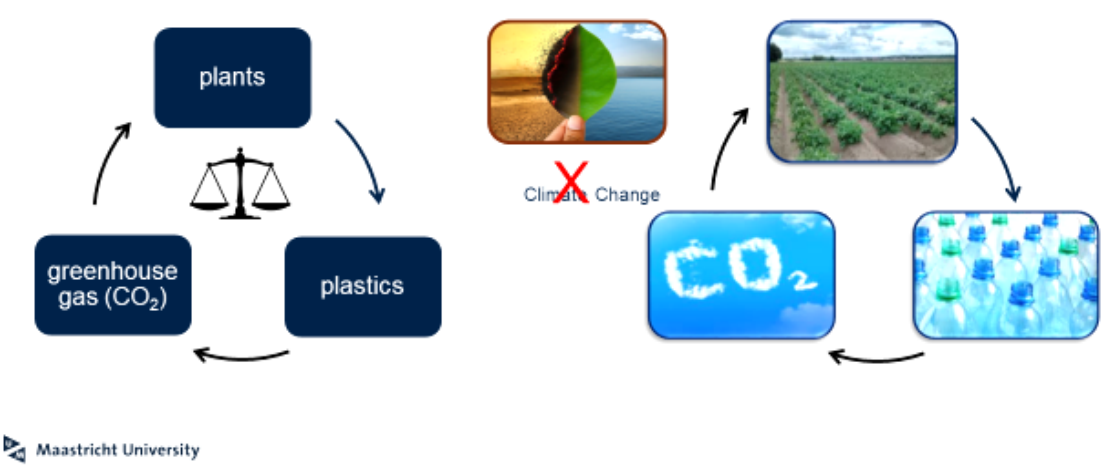

Dit is geen eenvoudige opgave. Eerst was de kwaliteit van bio-plastics, dat zijn plastics gemaakt uit gewassen zoals suikerriet, niet goed genoeg voor toepassing in bijvoorbeeld koffiebekertjes, maar dat is inmiddels wel gelukt. Toch kunnen bio-plastics nog niet voor alle toepassingen gebruikt worden en het marktaandeel is nog klein.

Plastics worden gemaakt uit polymeren. In 2018 werd slechts 2\% van de polymeren die wereldwijd geproduceerd werden uit biologische grondstoffen gemaakt [11]. 


\section{Plastic production and use}

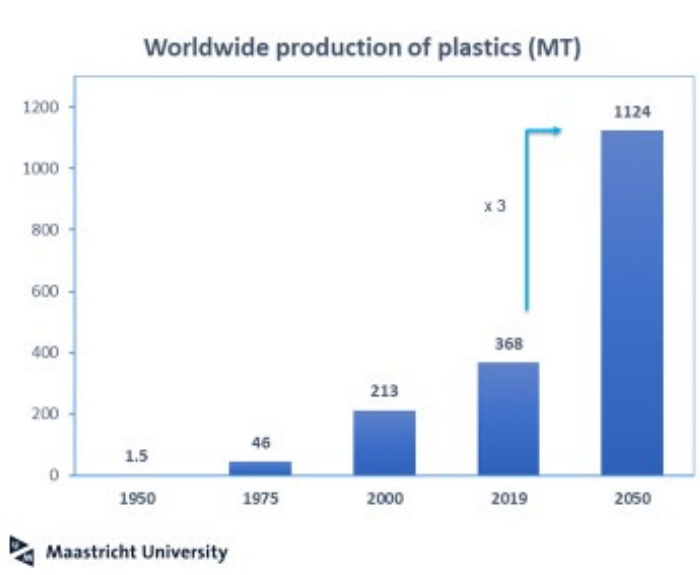

Applications

1. Packaging

2. Building \& construction

3. Automotive

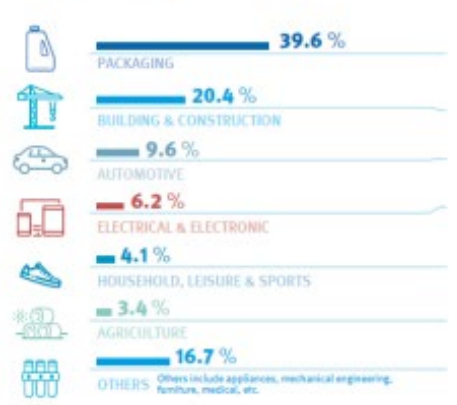

Elen MactArtur Foundsoson, 2016. Plassc Europe, 2020

Aangepast overgenomen uit [12,13]: PlascticEurope-Association of Plastics Manufactures. (2020). Plastics - the Facts 2020. PlasticEurope; World Economic Forum, Ellen MacArthur Foundation, \& McKinsey \& Company. (2016). The new plastics economy. Rethinking the future of plastics.

De productie van plastics zal de komende decennia nog met een factor 3 of 4 toenemen door een groeiende wereldbevolking en welvaart in de wereld. De klimaatimpact van plastics bedroeg in 2015

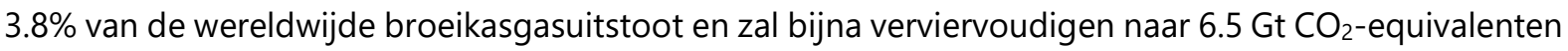
in 2050 [14], en dit in een periode waarin de klimaatimpact juist drastisch omlaag moet. Daarom moeten we overschakelen op biologische bronnen voor deze materialen; dit wordt ook wel de transitie naar een biobased economie genoemd.

\section{Environmental issues related to plastics}

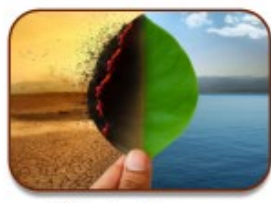

Climate Change

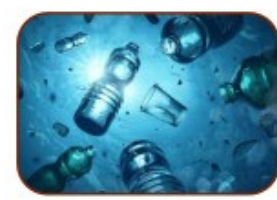

Plastic pollution

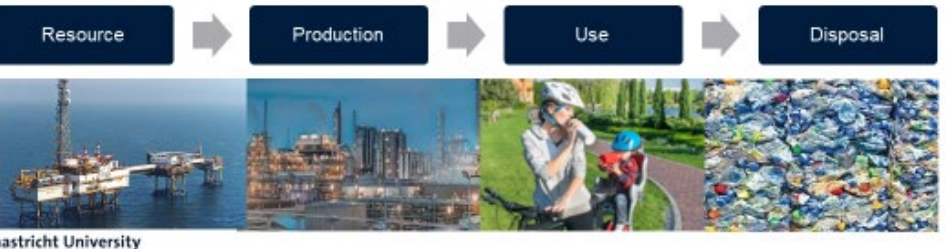

Maar daarmee zijn we er nog niet. Naast klimaatverandering, is vervuiling door plastics in ons milieu ook een groeiend probleem. Tot 2015 werd ongeveer 8300 miljard kilo plastic geproduceerd. Daarvan is in totaal $9 \%$ gerecycled, $12 \%$ verbrand en $79 \%$ gestort of in de natuur terecht gekomen. Exacte data van hoeveel plastic in de natuur is terecht gekomen zijn moeilijk te vinden. In 2010 is er naar schatting tussen de 4 en 12 miljard kilo plastic in zee terecht gekomen; dat is ongeveer 15000 kilo per minuut. Als de huidige trends in plastic productie en afvalbeheer doorzetten, zal tegen 2050 ruwweg 12000 miljard kilo plastic afval op stortplaatsen of in de natuur terechtgekomen zijn [15]. Dit plastic afval vervuilt 
bodem en water en komt via dieren ook in onze voedselketen terecht. Vervanging van fossiele plastics door bio-plastics lost dit probleem niet op, omdat bio-plastics vaak vergelijkbare negatieve milieueffecten hebben. We moeten dus het afvalbeheer van plastics verbeteren.

Door recycling en hergebruik van plastics voor nieuwe producten voorkomen we milieuvervuiling door afval. Tegelijkertijd wordt klimaatverandering hiermee ook tegengegaan, omdat de koolstof in de materialen behouden blijft in nieuwe producten en niet tot broeikasgas wordt omgevormd. Op dit moment kunnen veel plastic producten niet uit gerecycled materiaal gemaakt worden, omdat de kwaliteit van gerecycled plastic te laag is. Om de kwaliteit te verbeteren zijn betere scheidings- en recyclingtechnologieën nodig. Een tweede mogelijkheid is om plastic producten zo te ontwerpen dat zij beter geschikt zijn voor hergebruik of recycling, bijvoorbeeld door minder soorten plastics in één product te gebruiken of ervoor te zorgen dat het product na gebruik gemakkelijk uit elkaar gehaald kan worden. Er zijn op dit moment maar enkele voorbeelden van plastic producten die na afvalverwerking weer geschikt zijn om dezelfde functie te vervullen; we staan nog maar aan het begin van deze ontwikkeling, die ook wel de transitie naar een circulaire economie wordt genoemd. Onze maatschappij is nog niet ingericht op een circulaire aanpak; het vraagt een verandering van ons hele productie-, consumptie- en afvalsysteem.

\section{Recycled plastic as feedstock (future: circular)}

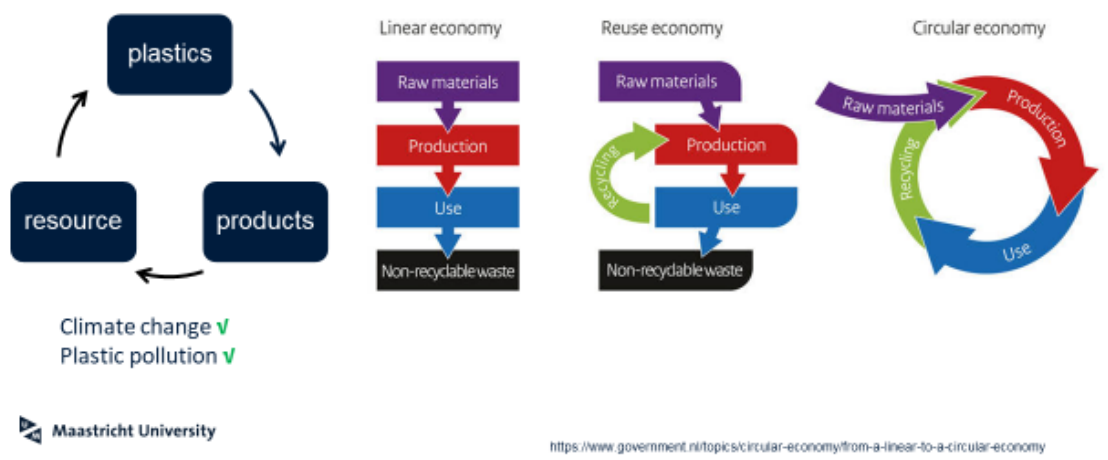

Overgenomen van [16]: Government of the Netherlands. (2018). From a linear to a circular economy | Circular economy | Government.nl. Retrieved June 8, 2021, from https://www.government.nl/topics/circular-economy/from-a-linear-to-a-circular-economy 
Het Aachen Maastricht Institute for Biobased Materials (AMIBM) waar mijn leerstoel onderdeel van uitmaakt, is volledig gericht op het realiseren van doorbraken in materialen die uit biologische grondstoffen zijn gemaakt, de zogenaamde biobased materialen. Het is een samenwerking tussen de Universiteit Maastricht en de RWTH Aken en die samenwerking heeft AMIBM een vliegende start gegeven. Ons instituut bestaat uit zeven onderzoeksgroepen die biologische, chemische, technologische en duurzaamheidsexpertise bij elkaar brengen waarmee de hele waardeketen van biobased materialen kan worden afgedekt. Een waardeketen omvat alle processtappen van grondstof naar chemische bouwstenen en materialen tot en met technische en medische toepassingen. Mijn onderzoeksgroep bestudeert duurzaamheid over deze hele waardeketen. Deze AMIBM-aanpak over de hele waardeketen is uniek en is erop gericht om veel sneller tot nieuwe en duurzame biobased materialen te komen door samenwerking over vakgebieden heen. Deze snelheid is ook maatschappelijk van belang, gezien de toenemende vraag naar materialen en de duurzaamheidsproblemen die we moeten oplossen.

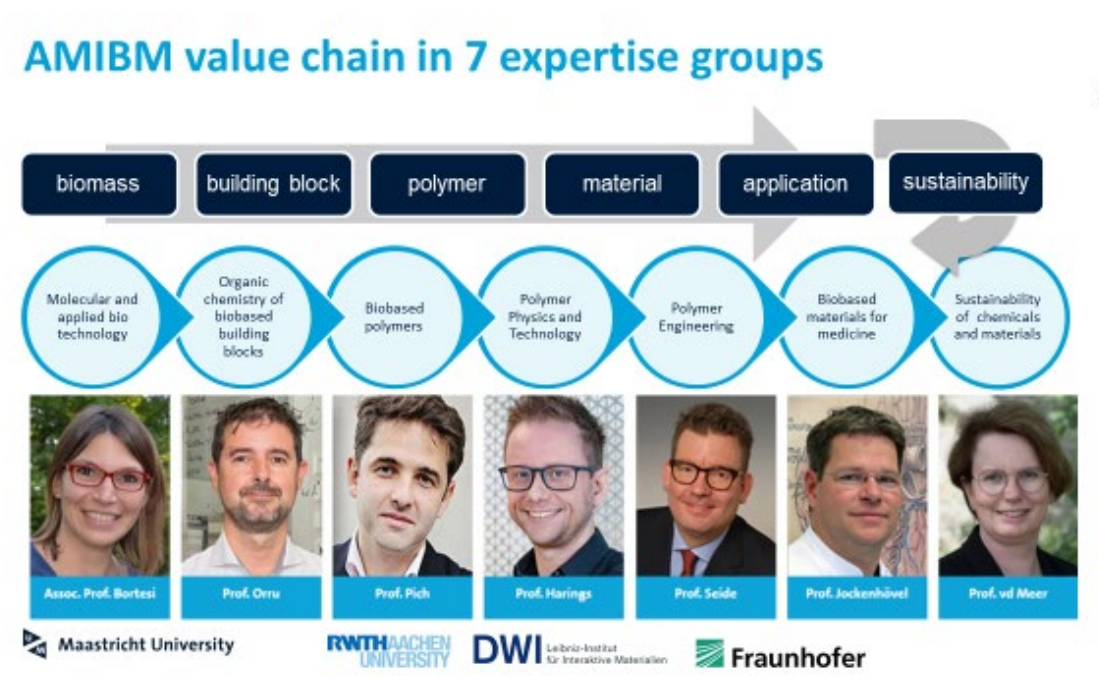

In het onderzoek werken we samen met universiteiten, kennispartners en bedrijven, waarbij AMIBM op elke plek in de waardeketen toegevoegde waarde creëert, door alle expertises die nodig zijn erbij te betrekken. We zoeken nadrukkelijk partnerschappen met het bedrijfsleven om nieuwe vindingen vanuit het instituut snel hun weg naar de toepassingen te laten vinden en om vraagstukken vanuit het bedrijfsleven goed te kunnen vertalen naar onderzoeksdoelstellingen, om zo met relevante vindingen en oplossingen te komen. Laagdrempelige interactie tussen AMIBM en bedrijfsleven bevordert dit proces. Dit is een belangrijke reden voor de vestiging van ons instituut op de Brightlands Chemelot Campus. We worden omgeven door een industrieel park van 800 hectare met chemische industrie op het Chemelot Industrial Park. Chemelot heeft de ambitie om in het jaar 2050 een circulaire, duurzame en volledig klimaat neutrale chemiesite te zijn; dit sluit direct aan bij de thema's waarop AMIBM onderzoek doet.

Maar ook internationaal heeft AMIBM veel samenwerkingspartners. In 2020 startte AMIBM als coördinator het Europese Industrial Doctorate programma Biobased Value Circle waarin 12 promovendi worden opgeleid; zij doen hun onderzoek in het bedrijfsleven en bij de universiteit. De missie van dit programma is om het innovatieproces voor biobased materialen te versnellen door integratie van disciplines en het ontwikkelen van een "gezamenlijke taal" om beter te kunnen communiceren tussen de vakgebieden. Zo leiden we goed getrainde pioniers op om de transitie naar een biobased en circulaire economie te versnellen. 


\section{Duurzaamheid van materialen}

Hiervoor heb ik twee routes genoemd hoe materialen duurzamer kunnen worden: door het gebruik van biologische grondstoffen en door afval te gebruiken als grondstof. Er zijn ook nog andere mogelijkheden; je kunt bijvoorbeeld het productieproces verbeteren. Maar hoe weten we eigenlijk hoe duurzaam een materiaal is? Daarvoor gaan we terug naar het begrip duurzame ontwikkeling. Duurzame ontwikkeling kun je beschouwen vanuit drie pijlers, de sociale, de milieu- en de economische pijler. Ons onderzoek richt zich in eerste instantie voornamelijk op de milieupijler. Levenscyclusanalyse (aangeduid als LCA) is een analytische methode om de effecten te bepalen van een product (of service) op het milieu. Dit maakt het mogelijk om producten op milieueffecten te vergelijken of te analyseren hoe de milieueffecten van een product verbeterd kunnen worden.

\section{Levenscyclusanalyse (LCA)}

Zoals de term al aangeeft, bekijken we de gehele levenscyclus van een product. Die begint met de grondstof, vervolgens het maken van het product, inclusief alle tussenstappen die daarvoor nodig zijn, het vervoer naar fabrieken en afzetmarkten, het gebruik en tenslotte de afvalverwerking. We noemen dit "van de wieg tot het graf". In circulaire termen wordt ook gesproken "van de wieg tot de wieg", om aan te geven dat afval weer gebruikt wordt als grondstof voor een volgend product.

Voor een LCA gelden ISO-normen, 14040 en 14044, die de verschillende stappen van een LCA met bijbehorende kwaliteitsvoorwaarden beschrijven. Ondanks deze standaardisatie, zijn er veel verschillende mogelijkheden om een LCA uit te voeren. Ze volgen wel allemaal vier stappen, waarbij tijdens de analyse heen en weer geschakeld wordt tussen deze stappen. In de eerste stap wordt beschreven wat het doel van de studie is en hoe de studie wordt afgebakend. Wat wordt wel en niet meegenomen, wat zijn de systeemgrenzen en voor wie zijn de uitkomsten bedoeld? Er kan ook besloten worden om slechts een deel van de levenscyclus te analyseren, bijvoorbeeld "van wieg tot

\section{Sustainability performance: Life Cycle Assessment}
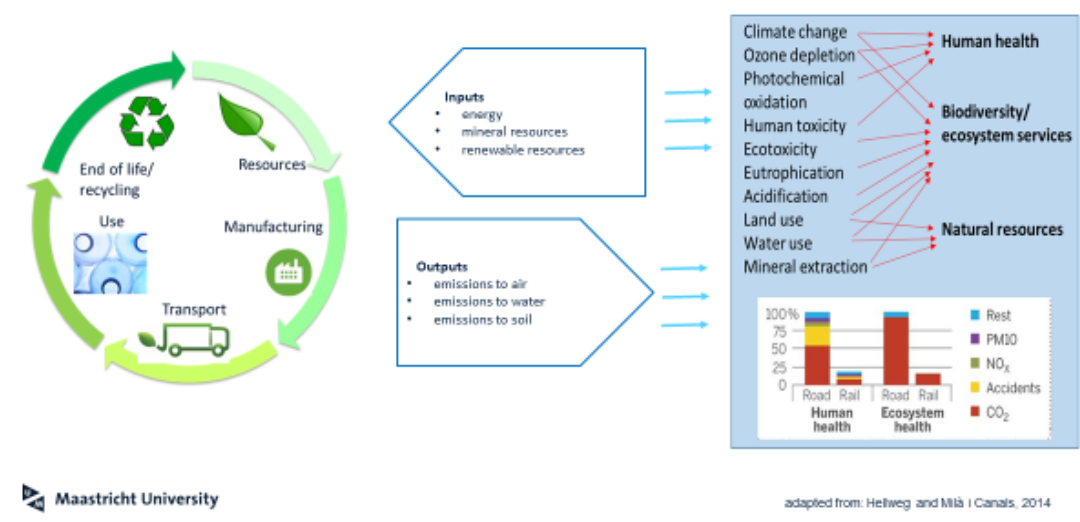

$\checkmark$ Maastricht University

Aangepast overgenomen uit [17]: Hellweg, S., \& Milà i Canals, L. (2014). Emerging approaches, challenges and opportunities in life cycle assessment. Science (New York, N.Y.), 344(6188), 1109-1113.

fabriekspoort". In deze stap wordt ook de functionele eenheid bepaald, de eenheid waarop de analyse gebaseerd wordt. De keuze voor deze eenheid is belangrijk en hangt samen met de definitie van de functie die vervuld wordt. Als voorbeeld kunnen we het drinken van koffie op een kantoor nemen. De functie kan zijn: het serveren van 500 kopjes koffie uit een koffieautomaat. Hiervoor heb je 1 beker nodig als je een mok gebruikt en 500 bekers als je plastic bekertjes uit de automaat gebruikt. De 
functionele eenheid corrigeert hiervoor, omdat de vergelijking is gebaseerd op de functie en niet op de hoeveelheid bekers. De tweede stap is het verzamelen van de data voor de studie. Het gaat om data van gebruik van water, grondstoffen, en energie en van de stoffen die terecht komen in de grond, het water en de lucht. Al deze gegevens worden verzameld en in stap 3 gegroepeerd op de soort milieueffecten die zij hebben. Vervolgens wordt bijvoorbeeld van alle broeikasgassen berekend wat dit betekent in termen van opwarming van de aarde. Zo kent de impactmethode ontwikkeld door het RIVM 18 verschillende indicatoren [18], waaronder klimaatimpact, verzuring, en schadelijkheid voor mensen. In de vierde en laatste stap worden de resultaten kritisch beoordeeld en wordt nagegaan wat de invloed van bepaalde aannames op de resultaten is. De resultaten zijn geen absoluut of definitief oordeel of een product duurzaam is of niet. LCA geeft een milieuprestatie weer binnen de gekozen randvoorwaarden van de studie die vermeld worden in het eindrapport.

De LCA-methodiek kan ook toegepast worden om een economische analyse te maken van de hele levenscyclus; dit heet Life Cycle Costing. Deze analyse heeft maar 1 impact, namelijk de kosten over de verschillende stadia van de levenscyclus, zoals de productiekosten, maar ook de onderhoudskosten en afvalkosten. Voor de derde pijler van duurzaamheid, is een sociale LCA-methode ontwikkeld. Sociale effecten zijn maar gedeeltelijk in getallen uit te drukken, waardoor deze methode ook kwalitatieve onderdelen heeft. De sociale LCA-methode is nog in ontwikkeling. Met de toenemende aandacht voor de effecten van industriële productie op mensen over de hele wereld, neemt de interesse voor sociale LCA de laatste jaren enorm toe.

\section{Ontwikkeling van nieuwe routes en technologieën met LCA}

Ik wil nu graag vertellen hoe we LCA gebruiken in ons onderzoek. De meeste LCA-studies bepalen de milieuprestatie van een bestaand product op basis van data die zo recent mogelijk zijn. In het onderzoek zijn we op zoek naar duurzame alternatieven voor de huidige chemische producten en materialen. Voor nieuwe technologieën of chemische routes, zou je graag willen voorspellen of dit tot milieuwinst gaat leiden in de toekomst; dit wordt vaak gedaan met ex-ante LCA. Je brengt dan in een vroeg stadium milieuprestaties in kaart en het voordeel hiervan is dat er in zo'n ontwikkelfase ook nog mogelijkheden zijn om veranderingen aan te brengen die de milieuprestaties kunnen verbeteren. Dit wordt ook gedaan met bepaalde vuistregels, bijvoorbeeld zo min mogelijk bijproducten maken in een chemische reactie, maar LCA geeft een holistischer beeld. Zo kun je met LCA beoordelen of een verbetering op één punt in een productiesysteem niet leidt tot verslechtering op andere punten, dus of er sprake is van nettowinst. Om veranderingen in de tijd te kunnen opnemen in de studie wordt dynamische LCA gebruikt. Daarnaast kennen we ook consequentiële LCA, waarbij activiteiten in een systeem aan elkaar worden gekoppeld en je kunt analyseren hoe milieueffecten zullen veranderen als gevolg van een aankoop- of beleidsbeslissing. Deze toekomstgerichte vormen van LCA kunnen krachtige instrumenten worden om versneld duurzame materialen te ontwikkelen, in een samenspel tussen materiaaleigenschappen en duurzaamheidscriteria. 
Er zijn nog wel wat uitdagingen. Allereerst vraagt het beoordelen van nieuwe technologieën in de toekomst om een schatting hoe de wereld eruitziet in 2030 of 2050, bijvoorbeeld wat betreft onze energievoorziening. Omdat er sprake is van systeemveranderingen, zullen we de nieuwe technologie bij voorkeur willen beoordelen als onderdeel van dit veranderde systeem en niet als een kleine verandering op zich. Ook moet een goede voorspelling gemaakt worden van de technologie op grotere schaal, bijvoorbeeld door processimulaties, omdat laboratoriumschaal niet representatief is voor industriële productie en we graag vergelijkingen willen maken met producten die al op de markt zijn. Tot slot hebben we met meer onzekerheden te maken, omdat we aannames doen over de toekomst, waardoor berekende grote verschillen binnen de onzekerheidsmarges kunnen komen te liggen, terwijl we juist uitspraken willen doen over wat de meest duurzame opties zijn.

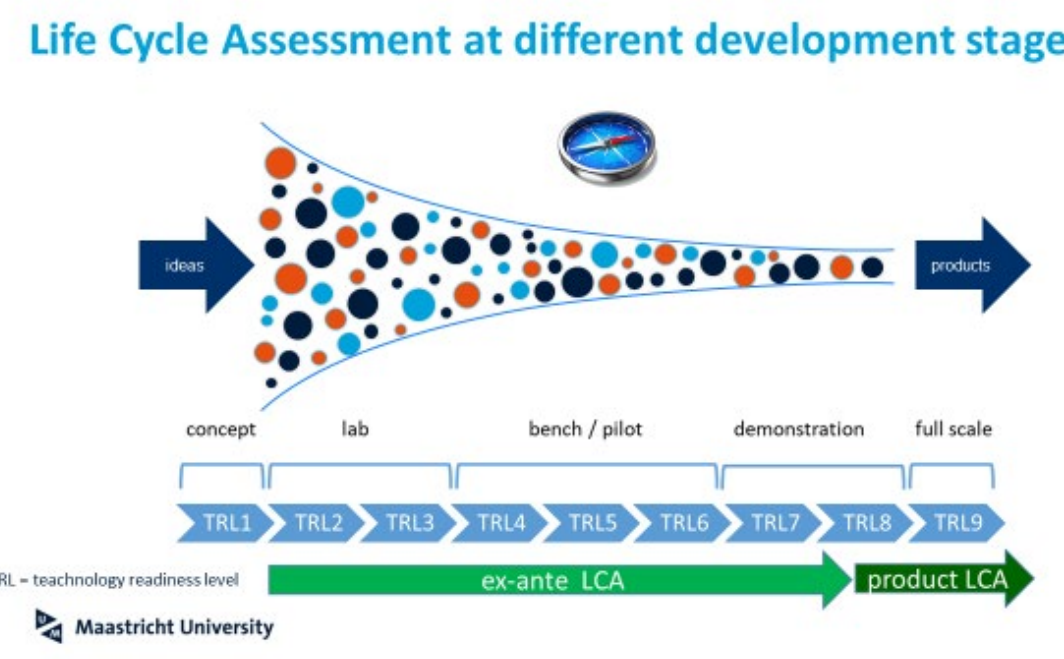

Hoewel vele onderzoeksprogramma's bol staan van de duurzaamheidsdoelstellingen en vragen om de milieueffecten te onderbouwen met LCA, is er maar weinig aandacht en geld voor de ontwikkeling van de LCA-methoden die de juiste antwoorden moeten geven. Er wordt geïnvesteerd in onderzoek dat duurzame oplossingen moet genereren, maar of we daarmee uiteindelijk duurzamer uit zijn is maar de vraag. Het is voor mij als alle zeilen bijzetten om het schip sneller te laten varen, maar geen geld investeren in het kompas dat de juiste koers moet aangeven. 


\section{Bioplastic sustainable?}

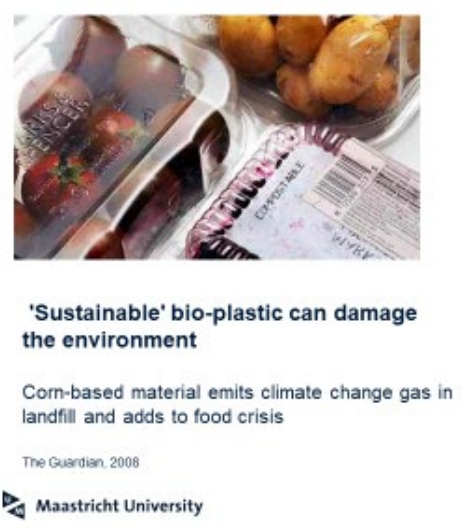

\section{Bioplastic: is it that fantastic?}

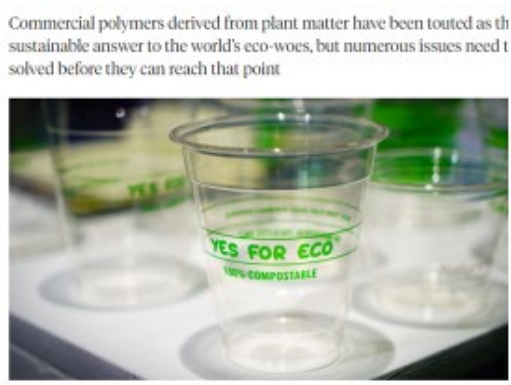

Overgenomen van The Guardian, 2008; https://www.raconteur.net/packaging/bioplastic-is-it-that-fantastic

Bij de eerste LCA-studies van bio-plastics werd vaak een lagere klimaatimpact gevonden dan bij de vergelijkbare fossiele plastics, zoals je zou verwachten door de gebalanceerde koolstofcyclus. Op de milieu-indicatoren aantasting van de ozonlaag en eutrofiëring, dat is een teveel aan voedingsstoffen die leidt tot een explosieve algengroei, scoren deze plastics doorgaans slechter; dit wordt veroorzaakt door de landbouw en kunstmest voor de biomassaproductie als gewassen worden gebruikt als grondstof [19]. Ook kan watergebruik een probleem zijn in gebieden waar waterschaarste is. Landgebruik werd een groot punt van discussie. Biobrandstoffen, zoals bio-ethanol, worden gemaakt uit gewassen als suikerriet en maïs, waarvoor veel land nodig is. Tegelijkertijd hebben we een groeiende wereldbevolking waarvoor voedsel geproduceerd moet worden. Zo ontstaat er concurrentie voor landbouwgronden en komt de voedselproductie in gevaar, terwijl natuurgebieden worden opgeofferd om extra landbouwgrond te creëren, waardoor er weer andere negatieve duurzaamheidseffecten optreden. Bovendien is uit onderzoek gebleken, dat landgebruik ook gepaard gaat met extra broeikasgasuitstoot, die niet in alle studies is meegenomen.

\section{Unintended Side Effects of Bioplastics: \\ Carbon footprint (GWP), Land Use and Water Footprint}
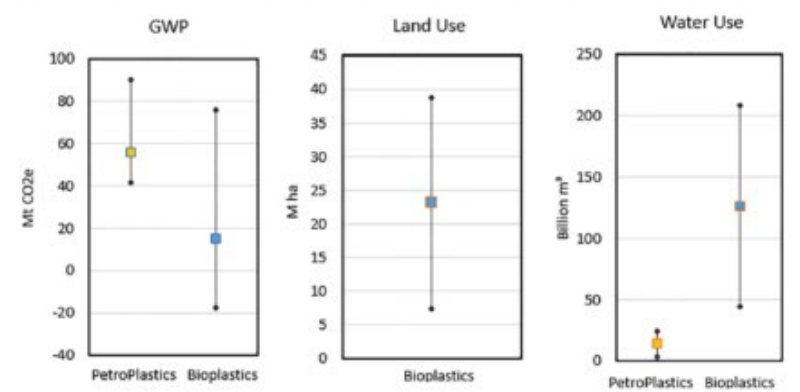

Maastricht University

Overgenomen van [20] Brizga, J., Hubacek, K., \& Feng, K. (2020, July 24). The Unintended Side Effects of Bioplastics: Carbon, Land, and Water Footprints. One Earth. 
Verder wordt de leveringsketen voor biomassa vaak weggelaten, waardoor uitstoot van broeikasgas door transport van biomassa naar verwerkingslocaties ontbreekt. Als deze effecten wel worden meegenomen, kan dit de klimaatwinst teniet doen of zelfs een hogere klimaatimpact voor bio-plastics opleveren dan voor fossiele plastics [19,20]. Verschillen tussen regio's in bodem en klimaat, maar ook de verschillen in de gevoeligheid voor bepaalde milieueffecten beïnvloeden de milieuprestatie. Om dit te kunnen meenemen, moeten we LCA-studies dus specifiek kunnen maken voor regio's, maar daarvoor ontbreken de data en modellen vaak nog voor. Dan wordt er met gemiddelden gewerkt van landen of werelddelen, waardoor de resultaten geen rekening houden met deze regionale verschillen.

De laatste jaren zijn er nieuwe generaties biomassabronnen in opmars: bijvoorbeeld kapafval van de bosbouw of afvalproducten van de landbouw. Deze bronnen vermijden extra landgebruik, maar het is wel moeilijker om hieruit de gewenste bouwstenen te halen voor bio-plastics. Ze bestaan uit meerdere bestanddelen die uit elkaar gehaald moeten worden. Dit wordt gedaan met bio-raffinageprocessen. De vraag is in welke gevallen dit netto milieuwinst gaat opleveren. Hier kun je LCA inzetten als tool om na te gaan hoeveel processtappen je je kunt veroorloven en welke processen het meest gunstig zijn voor de milieuprestatie.

Een bioraffinaderij levert diverse producten op en dan hebben we ook met een bekend LCA-probleem te maken: hoe rekenen we de milieueffecten toe aan de verschillende producten? We proberen allocatie, dat is het toewijzen van milieueffecten via een bepaalde verdeelsleutel, zoveel mogelijk te vermijden, omdat dit een vertekend beeld kan geven. Daarom werken we aan het gedetailleerd opsplitsen van de processen en het traceren van milieueffecten door het bio-raffinagesysteem heen, zodat allocatie tot een minimum wordt beperkt.

Er wordt ook onderzoek gedaan naar algen en zeewier als bron voor biobased producten; daarvoor is geen land nodig. Hierin combineren we LCA met Life Cycle Costing, om kritische factoren te identificeren voor de economische haalbaarheid en de milieuprestatie. Dat maakt het mogelijk om kosten en milieu tegen elkaar af te wegen om optimalisatiepunten te vinden, bijvoorbeeld zoveel mogelijk milieuwinst met zo min mogelijk additionele kosten.

\section{Rol van additieven}

We hebben nog niet gesproken over de andere componenten van plastics: additieven. Dit zijn chemische verbindingen die worden toegevoegd om de eigenschappen, de functie, of het uiterlijk van het plastic product te verbeteren. Hieronder vallen bijvoorbeeld weekmakers, kleurstoffen en vlamvertragers. Additieven worden in kleine of grote hoeveelheden toegevoegd aan plastics; dit kan oplopen tot wel 70 massaprocenten van het plastic product [21]. In ons instituut worden biobased additieven ontwikkeld, omdat we die nodig hebben als we materialen $100 \%$ biobased willen maken. Additieven kunnen grote milieueffecten hebben. Ook zijn er additieven die toxisch zijn, soms kankerverwekkend of leidend tot hormoonontregeling bij de mens. Toch worden additieven meestal buiten beschouwing gelaten in LCA-studies, omdat de samenstelling in veel gevallen niet bekend is [21]. Als we een compleet beeld willen hebben van de milieu- en gezondheidseffecten, dan moeten we dus eerst de gegevens van de additieven verzamelen om die te kunnen beoordelen. Informatie over deze 
additieven zal ook een grote rol gaan spelen bij nieuwe toepassingen van gerecycled materiaal. Als gerecycled plastic bijvoorbeeld gebruikt gaat worden als voedselverpakking, dan mogen bepaalde stoffen er niet in zitten, omdat die anders in ons voedsel terecht komen. Hiermee moet zoveel mogelijk rekening gehouden worden bij het ontwerpen van plastic producten om deze geschikt te maken voor recycling in de toekomstige circulaire economie.

\section{Additives}

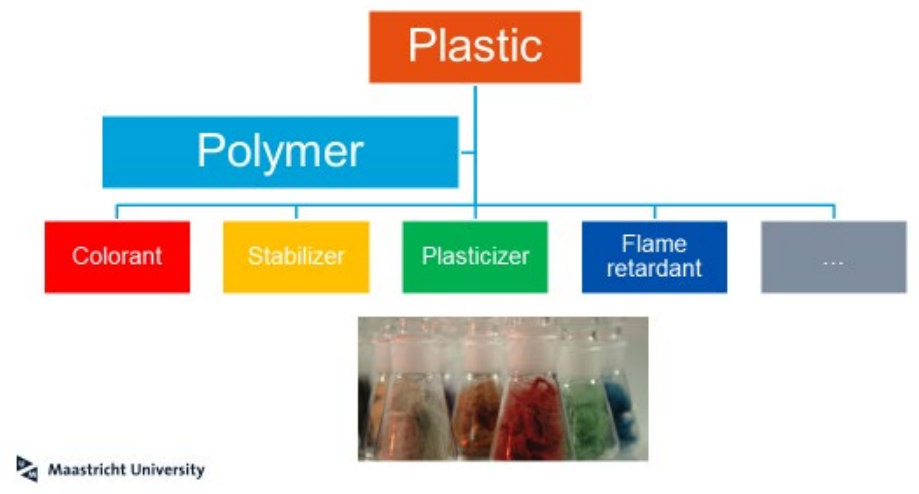




\section{Afval en circulariteit}

Als we afvalscenario's van plastics met LCA willen analyseren lopen we tegen verschillende problemen aan. De milieueffecten van plastic vervuiling in de oceaan kunnen niet berekend worden, omdat de impactmodellen daarvoor nog in ontwikkeling zijn. Recent zijn wel zwerfafvalindicatoren voorgesteld om het risico op zwerfafval te kunnen rapporteren,. Ook voor biologische afbreekbare plastics ontbreken nog gegevens en modellen om milieueffecten te kunnen berekenen voor realistische scenario's. Daarnaast is het modelleren van recycling in LCA nogal complex, omdat een product na recycling een volgend product wordt. Afhankelijk van het type recycling is dat een product met gelijkwaardige of lagere kwaliteit, maar het kan ook dat de polymeren of bouwstenen in heel andere producten terecht komen. De vraag is nu waar de grenzen tussen de levenscycli liggen en hoe we de milieueffecten verdelen over de producten. $\mathrm{Er}$ zijn verschillende aanpakken mogelijk en die hebben invloed op de milieuprestatie [23]. Verder spelen regionale verschillen een rol, omdat afvalsystemen in landen nogal van elkaar verschillen. De milieuprestatie van gerecycled plastic is ook afhankelijk van de kwaliteit van het ingezameld plastic, de transportafstanden, de processen die voor recycling gebruikt worden, dus ook hier kan telkens de balans opgemaakt worden wanneer er sprake is van netto milieuwinst.

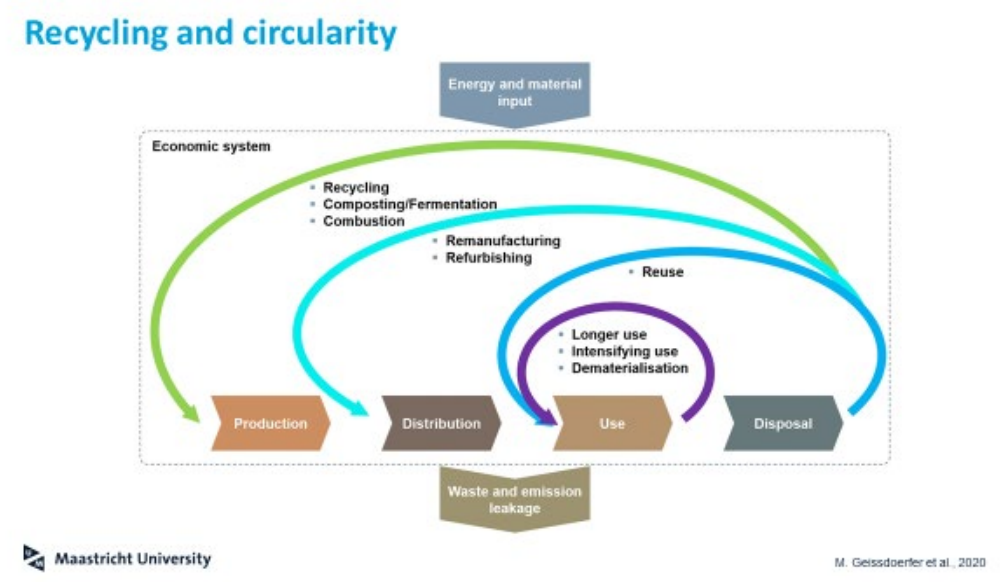

Overgenomen van [22]: Geissdoerfer, M., Pieroni, M. P. P., Pigosso, D. C. A., \& Soufani, K. (2020). Circular business models: A review. Journal of Cleaner Production, 277, 123741. https://doi.org/10.1016/j.jclepro.2020.123741

De term circulariteit houdt overigens veel meer in dan recycling, dat zich vooral focust op de materialen van een product. Je kunt bijvoorbeeld ook de levensduur verlengen van een product, producten hergebruiken of her-fabriceren. De vraag "hoe circulair is dit product?" en "hoe kunnen we de circulariteit van dit product verhogen?" proberen we te beantwoorden door het aanreiken van indicatoren die circulariteit op verschillende aspecten kunnen meten, waarbij we natuurlijk de connectie proberen te maken met de te verwachten duurzaamheidseffecten. 
Data

Ik wil graag ook kort ingaan op de benodigde data voor LCA-berekeningen. In ons onderzoek zijn we veel tijd kwijt aan het verkrijgen van deze data en we hebben vaak te maken met ontbrekende gegevens. Er komen wel steeds meer data beschikbaar in publicaties van bedrijven, overheden en wetenschappers, maar die bevinden zich in allerlei verschillende documenten, op veel verschillende plaatsen met verschillende kwaliteitsniveaus. Ik denk dat we veel vooruitgang kunnen boeken door samen te werken met datawetenschappers, enerzijds om data te lokaliseren en te verzamelen, anderzijds om betere manieren te vinden om data te rapporteren en te delen. Volledige transparantie van uitgevoerde berekeningen is in mijn ogen noodzakelijk. LCA-studies gebruiken niet altijd dezelfde aanpak, omdat de ISO-normen een raamwerk bieden met eigenlijk veel ruimte voor de manier van uitvoering. Er wordt gestreefd naar meer harmonisatie en dat bevordert de vergelijkbaarheid van studies, maar het kost veel tijd om tot consensus te komen en dit kan niet alle variaties afdekken. Toegang tot de achterliggende data en gebruikte modellen, biedt onderzoekers de mogelijkheid om deze data ook in andere studies te gebruiken, ook als voor andere methodieken wordt gekozen. Helaas gebeurt dit maar ten dele, zelfs in wetenschappelijke publicaties. Het zou een enorme vooruitgang zijn als de data van een LCA-studie ook gepubliceerd worden in afgesproken formats. Dit zou de kwaliteit en de snelheid van ons onderzoek bevorderen en ook de reputatie van LCA ten goede komen, omdat de variatie in uitkomsten dan beter verklaard en gecontroleerd kan worden.

\section{Data in LCA}
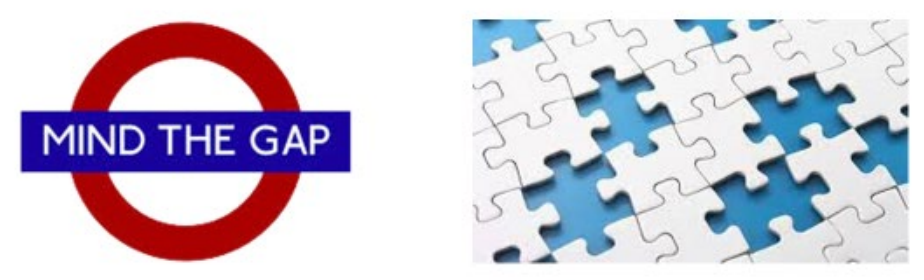

$\checkmark$ Maastricht University

Ik wil graag benadrukken dat ik hier een redelijk eenzijdig beeld geschetst heb van duurzaamheidsonderzoek vanuit de activiteiten die we doen in mijn onderzoeksgroep. Duurzaamheidsonderzoek kent vele aspecten en vraagt mijns inziens niet alleen samenwerking met onderzoekers in de bètawetenschappen, maar ook onderzoekers in de alfa- en gammawetenschappen. De Universiteit Maastricht staat bekend om de samenwerking over disciplines heen. Ik denk dat we dat ook op dit gebied kunnen realiseren, als we in staat zijn om de diverse onderzoekers die al aan duurzaamheid werken met elkaar te verbinden op thema's waar we het verschil kunnen maken. Dit wordt ondersteund door Sustainable UM 2030 en ik vind het een voorrecht om daar zelf ook een bijdrage aan te mogen leveren. 


\section{Onderwijs}

In het onderwijs vind ik het belangrijk dat we studenten leren denken vanuit een levenscyclus en vanuit de interactie van die levenscyclus met de wereld eromheen. De transitie naar een biobased en circulaire economie vraagt van studenten om de chemische, biologische en technologische ontwikkelingen ook te bekijken vanuit dit grotere en veranderende systeem, waarin naast ecologische, ook economische en sociale overwegingen een rol spelen. Aankomend academisch jaar gaan we op dit gebied onderwijs aanbieden in een vak in de nieuwe universiteit-brede Sustainability Minor, samen met het University College Maastricht en het Maastricht Sustainability Institute. Door het denken in levenscycli, kunnen we studenten uitdagen om na te denken over het herontwerpen van productiesystemen, in plaats van het optimaliseren van één processtap in zo'n productiesysteem. Dit gaan we doen in de nieuwe bachelor programma's business engineering en circular engineering.

Studenten die zich meer willen specialiseren in duurzaamheidsbeoordelingen, leren we om bestaande LCA-studies te begrijpen en ze kritisch te beoordelen en natuurlijk om zelf een studie uit te voeren [24].

\section{Teaching LCA on different levels}

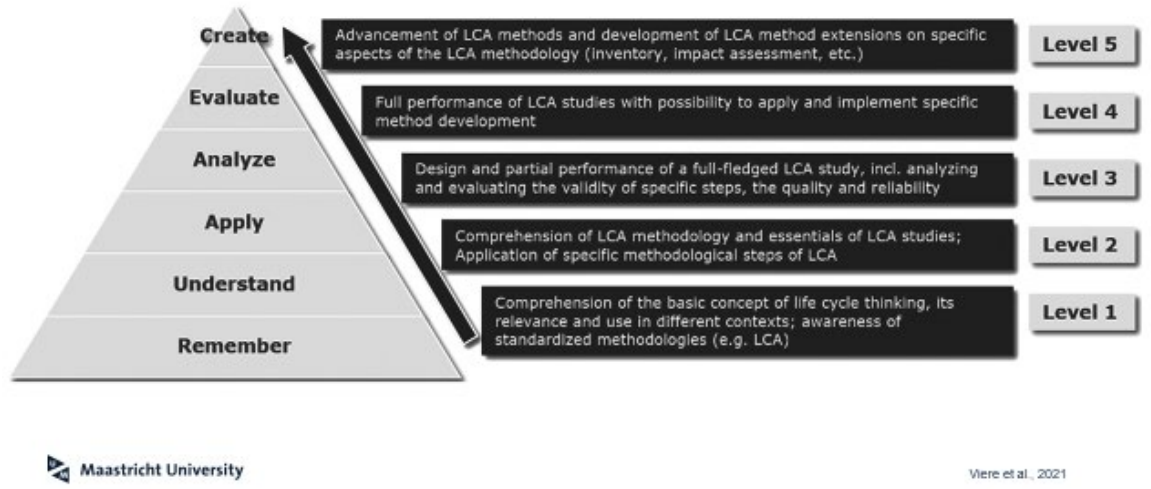

Overgenomen van [24]: Viere, T., Amor, B., Berger, N., Fanous, R.D., Arduin, R.H., Keller, R., Laurent, A., Loubet, P., Strothmann, P., Weyand, S., Wright, L., and Sonnemann, G. (2021). Teaching life cycle assessment in higher education. The International Journal of Life Cycle Assessment, 26(3), 511-527

Het Chemelot ecosysteem creëert hierin een unieke en inspirerende onderwijsomgeving, waarin vraagstukken uit de praktijk eenvoudig geïntegreerd worden in ons onderwijs en studenten ook de mogelijkheid hebben om al tijdens hun studie ervaring op te doen in de industrie.

We verzorgen ook onderwijs voor professionals. In samenwerking met Chemelot InSciTe hebben we onlineonderwijs ontwikkeld waarin de basisprincipes en het gebruik van LCA worden geïntroduceerd aan diegenen die nog nooit met LCA gewerkt hebben. Er is steeds meer vraag naar deze training met inmiddels deelnemers van over de hele wereld.

\section{Impact}

De afgelopen jaren is duurzaamheid voor overheden en industrieën een belangrijk criterium geworden bij de besluitvorming. $\mathrm{Er}$ is een toenemende vraag naar instrumenten en methoden om de duurzaamheidsprestaties van producten te meten en te vergelijken [25]. Resultaten moeten toegankelijk en begrijpelijk zijn voor iedereen die de resultaten wil gebruiken. Dit voorkomt ook verkeerd gebruik 
van de resultaten. Een LCA-studie levert vaak een palet van scores op van verschillende duurzaamheidseffecten die doorgaans niet dezelfde trends vertonen, waarbij vaak ook nog verschillende scenario's worden uitgewerkt; dit kan dus een complex verhaal worden. Voor de communicatie kan bijvoorbeeld een dashboard ontwikkeld worden waarop een bedrijf of overheid beslissingen kan baseren en voortgang kan bijhouden.

Ook voor consumenten is duurzaamheidsinformatie vaak lastig te beoordelen. Er zijn veel groene labels op de markt, die soms wél iets voorstellen en soms niet; er is veel "greenwashing", waarbij de consument wordt misleid wat betreft de duurzaamheid van het product. Het is voor consumenten niet eenvoudig om aan betrouwbare informatie over duurzaamheid te komen. Een initiatief als de KlimaatHelpdesk, waar iedereen een wetenschappelijk onderbouwd antwoord kan krijgen op klimaat gerelateerde vragen [26], ondersteun ik daarom van harte.

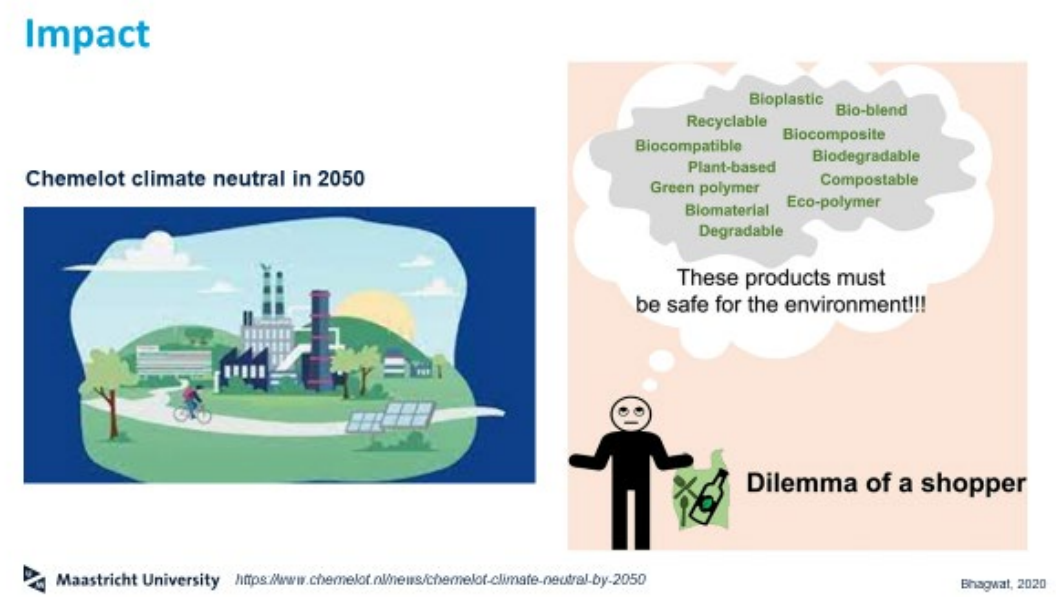

Overgenomen van: Chemelot. Chemelot climate neutral by 2050, from https://www.chemelot.nl/news/chemelot-climate-neutral-by-2050; [27] Bhagwat, G., Gray, K., Wilson, S. P., Muniyasamy, S., Vincent, S. G. T., Bush, R., \& Palanisami, T. (2020). Benchmarking Bioplastics: A Natural Step Towards a Sustainable Future. Journal of Polymers and the Environment, 28(12), 3055-3075.

Steeds meer consumenten willen af van plastic, omdat het geassocieerd wordt met milieuproblemen. Volgende maand gaat het Europese verbod op wegwerpplastic in en worden plastic wegwerpproducten vervangen door alternatieven [28]. Als we andere materialen gaan gebruiken voor hetzelfde type producten, dan komen die, als we ons gedrag niet aanpassen, nog steeds in het milieu terecht. Ik denk dat we zoveel mogelijk af moeten van producten die we maar zo kort gebruiken. Het blijkt ook lastig in te schatten of de alternatieven tot veel milieuwinst gaan leiden en er zijn nog maar weinig gegevens hierover beschikbaar. Hier ligt een taak voor de wetenschap om zoveel mogelijk betrouwbare informatie aan te leveren voor overheden, bedrijven en consumenten.

Ook binnen de Universiteit Maastricht is duurzaamheid de afgelopen jaren hoger op de agenda komen te staan. Ik heb bewondering voor de studenten die zich sterk maken voor een ambitieus duurzaamheidsbeleid in deze universiteit. Met de expertise die we in huis hebben en het enthousiasme van staf en studenten liggen er veel mogelijkheden om positieve resultaten te boeken. Het zou geweldig zijn als onze universiteit daarin een voortrekkersrol wil nemen. Zo kunnen we de daad bij het woord voegen en zelf laten zien hoe wetenschap kan bijdragen aan een duurzame wereld. 


\section{Slotwoord}

Hierbij ben ik aan het slot van mijn oratie gekomen. Ik wil graag iedereen bedanken die me de afgelopen jaren heeft gesteund op mijn pad naar het hoogleraarschap. Het was voor mij geen voor de hand liggende keuze. Toen ik in 2007 bij Ermo Daniels informeerde naar een mogelijke vacature bij de Universiteit Maastricht was ik op zoek naar een baan als beleidsmedewerker of subsidieadviseur, omdat ik daarvoor met veel plezier bij de nationale onderzoeksfinancier NWO had gewerkt. In 2008 ging ik aan de slag bij Academic Affairs en de Rechtenfaculteit als beleidsmedewerker en subsidieadviseur. Maar toen kwamen de Sciences en de Chemelot Campus op mijn pad. Er werd gesproken over het oprichten van een biobased materials programma samen met de dean Sciences, Frits van Merode. Ik wilde daar gaan aan bijdragen en stapte over naar de Sciences. De passie voor biobased die ik had meegekregen van Luuk van der Wielen tijdens het werken aan het B-BASIC programma van de TU Delft kwam goed van pas bij het uitwerken van het biobased onderzoeksprogramma. Menno Knetsch ontfermde zich over het biobased onderwijs met visie en passie, we waren echt een ijzersterk duo. Beste Frits, jij was het die me aanspoorde om na te denken over welke rol ik eigenlijk wilde spelen in de verdere uitbouw van de Biobased Materials. Ik moest even schakelen om je gedachtegang te volgen, maar ik realiseerde me al vrij snel dat ik mijn eigen onderzoeksgroep wilde opzetten en me als wetenschapper wilde bemoeien met duurzaamheidsdiscussies. Dankjewel daarvoor en voor alle steun, het heeft me zoveel moois gebracht. Ik wil het College van Bestuur, de decaan Thomas Cleij en de wetenschappelijk directeur van AMIBM Stefan Jockenhövel graag bedanken dat ik de mogelijkheid heb gekregen om deze nieuwe weg in te slaan. Ik wil ook Martin Paul bedanken, voor de steun die ik heb ervaren in mijn persoonlijke pad naar hoogleraar. Verder wil ik de biobased collega's van het eerste uur graag bedanken voor de plezierige samenwerking, de veerkracht die jullie getoond hebben en het fundament dat we samen gelegd hebben. Ik ben daar enorm trots op.

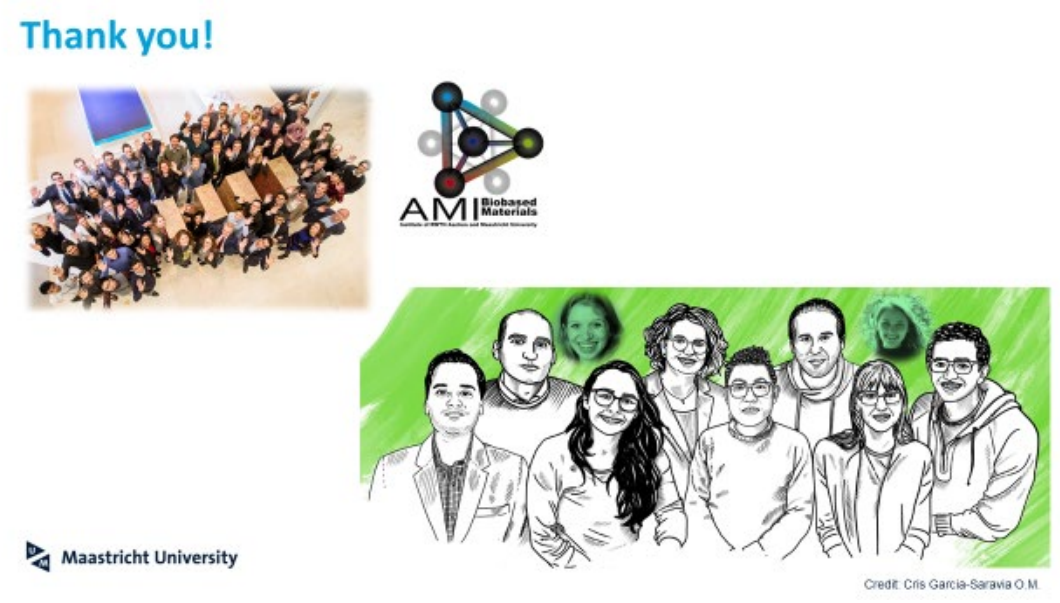

I am also very grateful to my group members who have stepped into this adventure with such enthusiasm in a completely new research group. Without you, ideas would have remained largely ideas, while we have already shown and established so much together. I look forward to continuing on this path together and I will always stand behind you.

Deze mijlpaal vandaag was er niet geweest zonder alle levenservaring die ik heb opgedaan buiten de wetenschap. Ik wil mijn gezin, familie, schoonfamilie en vrienden bedanken voor jullie onvoorwaardelijke steun en alle mooie momenten samen. 
De Club van Rome wilde snel actie ondernemen, te beginnen in 1975. Inmiddels is het 2021. Er is enorm veel gaande in het verduurzamen van onze samenleving, maar het gaat mij niet snel genoeg, de tijd dringt. Zoals altijd, ben ik wel hoopvol gestemd. We zullen dit wereldwijd met veel ambitie en tempo moeten oppakken. Ik probeer mijn bijdrage te leveren door steeds weer de vraag te beantwoorden "How sustainable is it?", "hoe duurzaam is het?". Ik hoop de komende jaren steeds vaker het antwoord te kunnen geven: Wow! Hiermee gaan we echt enorme stappen vooruit zetten!

Dank voor jullie aandacht. Ik heb gezegd. 


\section{Referenties}

1. Meadows, D.H., Meadows, D.L., Randers, J., and Behrens, W.W. (1972) The Limits to Growth: A report for the Club of Rome's Project on the Predicament of Mankind, Universe Books.

2. Randers, J. (2012) The Real Message of The Limits to Growth A Plea for Forward-Looking Global Policy. GAIA - Ecol. Perspect. Sci. Soc., 21 (2), 102-105.

3. Heijungs, R., Huppes, G., and Guinée, J.B. (2010) Life cycle assessment and sustainability analysis of products, materials and technologies. Toward a scientific framework for sustainability life cycle analysis. Polym. Degrad. Stab., 95 (3), 422-428.

4. World Commission on Environment and Development (1987) Our common future, Oxford; New York: Oxford University Press.

5. Elkington, J. (1998) Cannibals with forks: The triple bottom line of 21st century business, BC: New Society Publishers, Gabriola Island.

6. UNFCC (2015) ADOPTION OF THE PARIS AGREEMENT - Paris Agreement text English.

7. United Nations, D. of E. and S.A. (2020) THE 17 GOALS | Sustainable Development.

8. Jaramillo, F., and Destouni, G. (2015) Comment on "Planetary boundaries: Guiding human development on a changing planet." Science (80-. )., 348 (6240), 1217-1217.

9. Rockström, J., Steffen, W., Noone, K., Persson, Å., Chapin, F.S., Lambin, E.F., Lenton, T.M., Scheffer, M., Folke, C., Schellnhuber, H.J., Nykvist, B., De Wit, C.A., Hughes, T., Van Der Leeuw, S., Rodhe, H., Sörlin, S., Snyder, P.K., Costanza, R., Svedin, U., Falkenmark, M., Karlberg, L., Corell, R.W., Fabry, V.J., Hansen, J., Walker, B., Liverman, D., Richardson, K., Crutzen, P., and Foley, J.A. (2009) A safe operating space for humanity. Nature, 461 (7263), 472-475.

10. Materials frontier. Drivers for materials technology shifts.

11. Chinthapalli, R., Skoczinski, P., Carus, M., Baltus, W., de Guzman, D., Käb, H., Raschka, A., and Ravenstijn, J. (2019) Biobased Building Blocks and Polymers-Global Capacities, Production and Trends, 2018-2023. Ind. Biotechnol., 15 (4), 237-241.

12. PlascticEurope-Association of Plastics Manufactures (2020) Plastics - the Facts 2020. PlasticEurope.

13. World Economic Forum, Ellen MacArthur Foundation, and McKinsey \& Company (2016) The new plastics economy. Rethinking the future of plastics.

14. Zheng, J., and Suh, S. (2019) Strategies to reduce the global carbon footprint of plastics. Nat. Clim. Chang., 9 (5), 374-378.

15. Geyer, R., Jambeck, J.R., and Law, K.L. (2017) Production, use, and fate of all plastics ever made. Sci. Adv., 3 (7), e1700782.

16. Government of Netherlands (2018) From a linear to a circular economy | Circular economy | Government.nl. Gov. Netherlands.

17. Hellweg, S., and Milà i Canals, L. (2014) Emerging approaches, challenges and opportunities in life cycle assessment. Science, 344 (6188), 1109-13.

18. Huijbregts, M.A.J., Steinmann, Z.J.N., Elshout, P.M.F., Stam, G., Verones, F., Vieira, M., Zijp, M., Hollander, A., and van Zelm, R. (2017) ReCiPe2016: a harmonised life cycle impact assessment method at midpoint and endpoint level. Int. J. Life Cycle Assess., 22 (2), 138-147.

19. Weiss, M., Haufe, J., Carus, M., Brandão, M., Bringezu, S., Hermann, B., and Patel, M.K. (2012) A Review of the Environmental Impacts of Biobased Materials. J. Ind. Ecol., 16, S169-S181.

20. Brizga, J., Hubacek, K., and Feng, K. (2020) The Unintended Side Effects of Bioplastics: Carbon, Land, and Water Footprints. One Earth, 3 (1), 45-53.

21. Bishop, G., Styles, D., and Lens, P.N.L. (2021) Environmental performance comparison of bioplastics and petrochemical plastics: A review of life cycle assessment (LCA) methodological decisions. Resour. Conserv. Recycl., 168, 105451.

22. Geissdoerfer, M., Pieroni, M.P.P., Pigosso, D.C.A., and Soufani, K. (2020) Circular business models: A review. J. Clean. Prod., 277, 123741.

23. Ekvall, T., Björklund, A., Sandin, G., Jelse, K., Lagergren, J., and Rydberg, M. (2020) Modeling recycling in life cycle assessment.

24. Viere, T., Amor, B., Berger, N., Fanous, R.D., Arduin, R.H., Keller, R., Laurent, A., Loubet, P., Strothmann, P., Weyand, S., Wright, L., and Sonnemann, G. (2021) Teaching life cycle assessment in higher education. Int. J. Life Cycle Assess., 26 (3), 511-527.

25. Sala, S., Ciuffo, B., and Nijkamp, P. (2015) A systemic framework for sustainability assessment. Ecol. Econ., 119, 314325.

26. KlimaatHelpdesk KlimaatHelpdesk.

27. Bhagwat, G., Gray, K., Wilson, S.P., Muniyasamy, S., Vincent, S.G.T., Bush, R., and Palanisami, T. (2020) Benchmarking Bioplastics: A Natural Step Towards a Sustainable Future. J. Polym. Environ., 28 (12), 3055-3075.

28. Europese richtlijn voor minder wegwerpplastic in zee (SUP-richtlijn) | Afval | Rijksoverheid.nl. Rijksoverheid.nl. 